\section{Commentary: Overreliance of propensity-score matched studies in thoracic surgery}

\author{
Travis C. Geraci, MD, ${ }^{\mathrm{a}}$ and Thomas $\mathrm{Ng}, \mathrm{MD}^{\mathrm{b}}$
}

In a well-executed, propensity score-matched study published in this issue of the Journal, Xie and colleagues ${ }^{1}$ report superior perioperative outcomes with videoassisted thoracoscopic surgery (VATS) sleeve lobectomy compared with thoracotomy. Specifically, VATS was associated with less operative blood loss, fewer days in the intensive care unit, shorter chest tube duration, and shorter hospital stay. Unfortunately, the authors omitted their methods of analgesia and did not report data regarding postoperative pain, readmission, functional recovery, or quality of life. Of note, this study reflects outcomes from experienced VATS surgeons, as the authors performed more than 50 cases of VATS sleeve lobectomy before enrollment and $70 \%$ of VATS cases employed a uniportal technique.

Despite superior perioperative outcomes with VATS, there were no statistical differences in major morbidity or 30- and 90-day mortality. Equally, at an approximate 3-year follow-up, recurrence-free and overall survival were similar. In assessing survival, the patients were well balanced, but the criteria for multivariate analysis regarding tumor biology were somewhat imprecise: pathology was only differentiated by squamous histology (or not) and overall TMN stage.

In summary, for a complicated procedure such as sleeve lobectomy, the data do not provide a clear directive regarding approach, but rather-to use the authors' own words- "the decision to perform sleeve lobectomy by either approach remains [was] based on surgeon's preference." Given the limited number of patients who require sleeve resection, this propensity-matched cohort of 188 patients (116 thoracotomy, 72 VATS) is

From the a Department of Cardiothoracic Surgery, New York University-Langone Health, New York, NY; and ${ }^{\mathrm{b}}$ Department of Surgery, Warren Alpert Medical School of Brown University, Providence, RI.

Disclosures: Authors have nothing to disclose with regard to commercial support. Received for publication Feb 12, 2020; accepted for publication Feb 15, 2020; available ahead of print Feb 21, 2020.

Address for reprints: Thomas Ng, MD, 2 Dudley St, Suite 470, Providence, RI 02905 (E-mail: thomas.ng@brownphysicians.org).

J Thorac Cardiovasc Surg 2021;161:417-8

$0022-5223 / \$ 36.00$

Copyright (c) 2020 by The American Association for Thoracic Surgery

https://doi.org/10.1016/j.jtcvs.2020.02.068

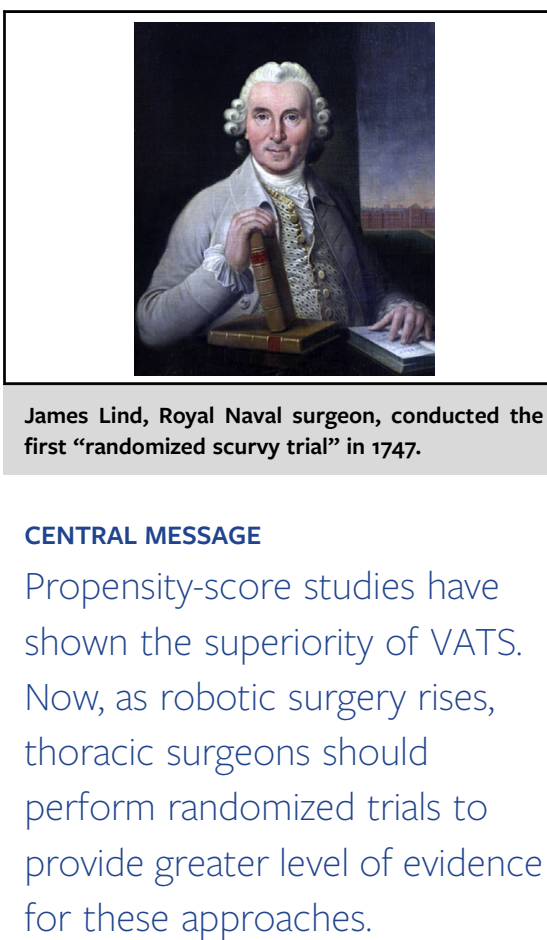

laudable. However, despite the efforts of the researchers to balance the patient arms and select the appropriate variables for analysis, the data remain open to confounding and selection bias. Perhaps thoracic surgeons have overly relied on propensity score-matching studies to determine "the standard of care." Why are we less fervent regarding our statistical approach than our surgical one?

Over the last decade, we have seen numerous propensity score match studies comparing VATS versus thoracotomy for pulmonary lobectomy: data derived from large national databases such as the Society of Thoracic Surgeons database, ${ }^{2,3}$ the American College of Surgeons National Surgical Quality Improvement Program database, ${ }^{4}$ the Nationwide Inpatient Sample database, ${ }^{5}$ the Surveillance Epidemiology and End Results-Medicare database, ${ }^{6}$ the Premier Prospective Database, ${ }^{7}$ and the National Cancer Data Base, ${ }^{8}$ all overwhelmingly reported superior outcomes for VATS versus thoracotomy. This evidence against thoracotomy seems insurmountable, but can we honestly declare VATS the "gold standard" approach for lobectomy in the absence of a well-designed multicenter randomized trial? As stated by the statistical editor of our Journal, Dr Blackstone, "balancing score methods are not substitutes for a properly designed randomized trial; they cannot account 
for unknown variables affecting outcome that are not correlated strongly with measured variables, they lack discipline and rigor of a randomized trial." Furthermore, thoracic surgeons have seemingly lost their equipoise to enroll patients in randomized studies: minimally invasive surgeons remain concerned over the unnecessary potential morbidity of a thoracotomy, and open surgeons may not be comfortable performing minimally invasive operations. Thoracic surgeons must set aside their biases and enroll patients in randomized trials for the benefit of the entire community.

The same questions posed regarding VATS versus thoracotomy will be continually revisited as new minimally invasive techniques and technologies-including robotic surgery-challenge traditional approaches to VATS. A randomized trial may seem arduous an inefficient, but the feasibility of completing these studies in thoracic surgery is exemplified by the TIME (Traditional Invasive vs Minimally invasive Esophagectomy) trial, the MIRO trial, and the ongoing ROMIO (Randomised Oesophagectomy: Minimally Invasive or Open) trial, ${ }^{10}$ which compare minimally invasive approaches against open esophagectomy. As a community of surgeons, our investments in high-quality research will assure we are providing our patients with optimal care and are not merely approximating excellence.

\section{References}

1. Xie D, Deng J, Gonzalez-Rivas D, Zhu Y, Jiang L, Jiang G, et al. Comparison of video-assisted thoracoscopic surgery with thoracotomy in bronchial sleeve lobectomy for centrally located non-small cell lung cancer. J Thorac Cardiovasc Surg. 2021;161:403-13.e2.

2. Paul S, Altorki NK, Sheng S, Lee PC, Harpole DH, Onaitis MW, et al. Thoracoscopic lobectomy is associated with lower morbidity than open lobectomy: a propensity-matched analysis from the STS database. J Thorac Cardiovasc Surg. 2010;139:366-78.

3. Boffa DJ, Dhamija A, Kosinski AS, Kim AW, Detterbeck FC, Mitchell JD, et al. Fewer complications result from a video-assisted approach to anatomic resection of clinical stage I lung cancer. J Thorac Cardiovasc Surg. 2014;148:637-43.

4. Phillips JD, Merkow RP, Sherman KL, DeCamp MM, Bentrem DJ, Bilimoria KY. Factors affecting selection of operative approach and subsequent short-term outcomes after anatomic resection for lung cancer. J Am Coll Surg. 2012;215:206-15.

5. Paul S, Sedrakyan A, Chiu YL, Nasar A, Port JL, Lee PC, et al. Outcomes after lobectomy using thoracoscopy vs thoracotomy: a comparative effectiveness analysis utilizing the Nationwide Inpatient Sample database. Eur J Cardiothorac Surg. 2013;43:813-7.

6. Paul S, Isaacs AJ, Treasure T, Altorki NK, Sedrakyan A. Long term survival with thoracoscopic versus open lobectomy: propensity matched comparative analysis using SEER-Medicare database. BMJ. 2014;349:g5575.

7. Blasberg JD, Seder CW, Leverson G, Shan Y, Maloney JD, Macke RA. Video-assisted thoracoscopic lobectomy for lung cancer: current practice patterns and predictors of adoption. Ann Thorac Surg. 2016;102:1854-62.

8. Yang CF, Sun Z, Speicher PJ, Saud SM, Gulack BC, Hartwig MG, et al. Use and outcomes of minimally invasive lobectomy for stage I non-small cell lung cancer in the National Cancer Data Base. Ann Thorac Surg. 2016;101:1037-42.

9. Blackstone EH. Comparing apples and oranges. J Thorac Cardiovasc Surg. 2002; 123:8-15.

10. Hofstetter WL. Open versus hybrid minimally invasive esophagectomy: join the crowd, but do not throw away your abdominal retractors just yet. $J$ Thorac Cardiovasc Surg. 2019;158:1475-8. 